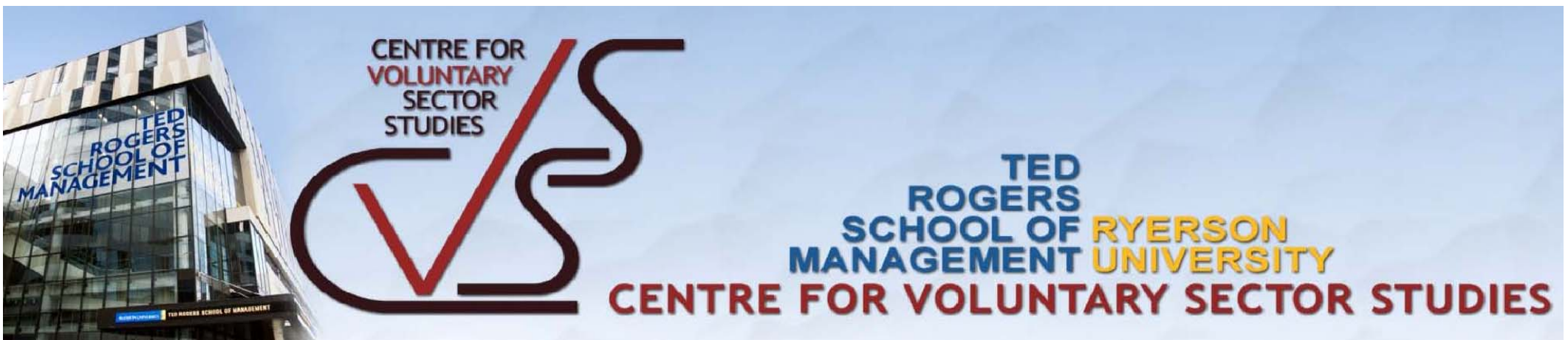

\title{
Benefits and Challenges to People with Psychiatric Disabilities Who Volunteer
}

\author{
Agnes Meinhard \\ Centre for Voluntary Sector Studies, Ryerson University \\ Itay Greenspan \\ School of Social Policy and Practice, University of Pennsylvania \\ Jennifer Paterson \\ School of Disability Studies, York University \\ Phaedra Livingstone \\ Centre for Voluntary Sector Studies, Ryerson University
}

Working paper series

Volume 2007 (3)

350 Victoria Street

Toronto, Ontario M5B 2K3

Tel: 416-979-5146 x 6739 / Fax: 416-979-5124

cvss@ryerson.ca

http://www.ryerson.ca/cvss/working_papers 


\section{Introduction $^{1}$}

This research follows from the research reported in CVSS Working Paper Series, Volume 2007 (2). In that paper we presented the results of our examination of volunteer programs in ten organizations serving people with psychiatric disabilities ${ }^{2}$. We described the nature of the programs, identified best practices and discussed the challenges and benefits they presented. This paper focuses on the responses of 27 people with psychiatric disabilities to a questionnaire probing their volunteering experiences. Please refer to the previous CVSS Working Paper titled "Client Volunteering in Organizations Serving Individuals with Psychiatric Disabilities" for a detailed review of the literature. Here we will briefly summarize the major thrust of the literature review.

In recent decades, the mental health systems in Canada and the U.S. have moved through a significant paradigm shift in the treatment of mental illness. A combination of medication treatment and the development of community-based rehabilitation programs shifted the focus of care from hospitals and institutions to the community in a process identified as deinstitutionalization of the mental health system (Roeher Institute, 1990, 1999; Stroman, 2003). Consequently, community vocational rehabilitation programs for skills building and job training, such as consumer/survivor-run businesses and Assertive Community Treatment (ASTs), have been on the rise. Earlier research pointed out that the change from institutions to the community has had a positive influence on the lives of people with mental illness, their families, and caregivers (Becker \& Drake, 2003; Goering, 2004). Clients experienced an improvement in their daily living and a reduction in symptoms and substance abuse; they were also subject to fewer crisis episodes and spent far fewer days in hospital.

Client-volunteering programs in mental health services are a relatively new development in integrating people with psychiatric disabilities into society (Cook \& Picket, 1994; Firth \& Kerfoot, 1997; Weaver, 1993). Research indicates that there are several different types of organizations providing volunteer opportunities for people with psychiatric disabilities: educational institutions, job placement organizations, supportive housing agencies, clinics, rehabilitation centres and drop-in centres. In some of these organizations, volunteering is part of a formal program, whereas in others, it is more informal but definitely encouraged and supported. Some organizations provide in-house opportunities to volunteer, while others encourage, support or arrange volunteering with outside agencies (Meinhard et al., 2006). In some of these programs volunteering is seen as a stepping-stone towards finding a permanent job; in others volunteering is part of rehabilitation and personal recovery, or a means for community and social integration, but not as a route to gainful employment.

Although society-at-large generally views volunteering in a positive manner, some of society's disadvantaged members may see it as a less than desirable alternative to paid

\footnotetext{
${ }^{1}$ This research was partially supported by a Social Sciences and Humanities Research Council of Canada Institutional Grant

${ }^{2}$ For the purpose of this paper, the terms psychiatric disability, client, consumer, survivor, volunteer and participant are used interchangeably, reflecting the diversity of terms used in the interviews we conducted. In the literature, there is much debate over definitions and terminology such as mental versus psychiatric and impairment, illness or disability. Some people who have experienced the mental health system self-define as a 'consumer' or 'survivor'.
} 
employment (Crawford, 2004). According to the Canadian Council on Social Development, three times as many disabled men and twice as many disabled women were out of work in 2000 than their non-disabled peers. As people with psychiatric disabilities typically experience significant barriers to obtaining paid employment, for some there is a stigma associated with volunteering.

Given this ambivalence towards volunteering, we are surveying volunteers with psychiatric disabilities in order to understand their opinions and experiences. The survey questionnaire consists of 24 questions, some with close-ended choices and others with openended answers. Questions cover topics such as type of placement, volunteer tasks, length of time at placement, frequency of volunteering, support and training, helpfulness of support, enjoyment of tasks, effects of volunteering on personal well-being and job prospects, attitudes about volunteering and work, and their suggestions for improving volunteer programs.

\section{Methods}

In order to address the lack of research on volunteering among people with psychiatric disabilities, we studied ten volunteering programs in the Greater Toronto Area. At last year's Arnova conference we described the volunteer programs offered to people with psychiatric disabilities in these ten organizations. In this paper, we evaluate the impact of volunteering, as reported by the volunteers, on their general well-being and their integration into community.

\section{Sample}

Our sample is by necessity, a purposive sample attained through advertising at the ten centres that we studied. Advertisements explaining the research were distributed to prospective respondents by the volunteer coordinators we interviewed. They were also tacked to bulletin boards frequented by the client volunteers The ads explained the purpose and nature of the research, the time it would take to complete a telephone interview, and the telephone number to call in order to participate. Prominently displayed on the ad was the promise of a reward of a $\$ 10$ coupon to Tim Horton's, Canada's most popular coffee and doughnut shop, to everyone who completed the oral survey. Thirty people called and we obtained 27 completed interviews.

\section{Questionnaire}

The questionnaire probed six aspects of their volunteering experience:

- The nature, frequency, place and length of volunteering

- Reasons for volunteering

- Kinds of supports and training offered to the volunteer

- Volunteering experiences: what they learned, what was frustrating/satisfying

- Impact of their volunteering on their health and well-being, their job prospects and their connection to community

- Suggestions for program features: "If someone wanted to set up a volunteer program for people with psychiatric disabilities, what would you suggest is necessary to create a successful volunteer program?” 
Before beginning the telephone interview, we read out the terms of informed consent required by Ryerson's Ethical Review Board.

\section{Analysis}

There were 24 questions on the questionnaire. Two required answers according to a fivepoint Lickert scale; these were the only two questions in which the interviewer read the answer categories to the respondent. All the other questions were asked without providing answer categories, even the yes/no questions. Responses to the open-ended questions were analyzed, and then categorized.

\section{Findings}

\section{Nature of Volunteering}

Our respondents were all clients of organizations that provided services for people with psychiatric disabilities. Since close to $40 \%$ of our respondents had more than one volunteer placements, we recorded 53 volunteering activities that correspond to the twelve categories listed in Table 1.

Table 1. Types and location of volunteer activities.

\begin{tabular}{|c|c|c|c|c|c|c|}
\hline Activities & Frequency & $\%$ & In-house & $\%$ & Outside & $\%$ \\
\hline Food/cafeteria & 8 & $\begin{array}{l}15 . \\
1\end{array}$ & 6 & 75 & 2 & 25 \\
\hline Religious activities/ Church & 7 & $\begin{array}{l}13 . \\
2\end{array}$ & 0 & 0 & 7 & 100 \\
\hline Clerical & 7 & $\begin{array}{l}13 . \\
2\end{array}$ & 4 & $\begin{array}{l}57 . \\
1\end{array}$ & 3 & $\begin{array}{l}42 . \\
9\end{array}$ \\
\hline Cleaning duties & 6 & $\begin{array}{l}11 . \\
3\end{array}$ & 6 & 100 & 0 & 0 \\
\hline $\begin{array}{l}\text { Misc. (fundraising, customer service, } \\
\text { rallies) }\end{array}$ & 6 & $\begin{array}{l}11 . \\
3\end{array}$ & 3 & 50 & 3 & 50 \\
\hline Board/committee work & 4 & $\begin{array}{l}7.5 \\
5\end{array}$ & 4 & 100 & 0 & 0 \\
\hline Newsletter/writing & 3 & $\begin{array}{l}5.6 \\
6\end{array}$ & 3 & 100 & 0 & 0 \\
\hline Tutoring/teaching assistant & 3 & $\begin{array}{l}5.6 \\
6\end{array}$ & 1 & $\begin{array}{l}33 . \\
3\end{array}$ & 2 & $\begin{array}{l}66 . \\
7\end{array}$ \\
\hline Volunteering at drop-in centre & 3 & $\begin{array}{l}5.6 \\
6\end{array}$ & 3 & 100 & 0 & 0 \\
\hline Shopping & 2 & $\begin{array}{l}3.7 \\
7\end{array}$ & 2 & 100 & 0 & 0 \\
\hline Working with older people & 2 & $\begin{array}{l}3.7 \\
7\end{array}$ & 0 & 0 & 2 & 100 \\
\hline
\end{tabular}




\begin{tabular}{lllllll}
\hline Special events & 2 & 3.7 & 2 & 100 & 0 & 0 \\
Total & 53 & $\mathbf{1 0 0}$ & 34 & $\mathbf{6 4 .}$ & $\mathbf{1 9}$ & $\begin{array}{l}\mathbf{3 5 .} \\
\mathbf{8}\end{array}$ \\
\hline
\end{tabular}

Almost two thirds of the volunteering took place in-house (in the organization that the respondent was affiliated with) and much of that revolved around cleaning in the common areas and food preparation in the organization's cafeteria.

For slightly more than one third of the respondents, the current volunteer placement was their first. The range of experience varied widely, from one month to 20 years. The average number of years of volunteering experience was 6.2, but the median, which in this case is a more accurate indicator, was only 3.2 years. Seventy percent of respondents volunteered weekly, 62\% at the same time each week. Twenty-four percent volunteered monthly, mostly at different times a month. One client volunteered twice a month and another episodically. The median weekly hours spent volunteering was six hours (mean=12hours), but the range was very broad, from one hour a month to 40 hours a week.

\section{Reasons for volunteering}

Our respondents volunteered for a variety of reasons, as listed in Table 2. The predominant reasons relate to their isolation from general society: More than half our respondents volunteer to meet with people and to get out of house. Helping others and giving back to the community, the top reasons given by volunteers in general (NSGVP), although still important to this group of respondents, are less frequently mentioned together accounting for $40 \%$ of the responses. (In some instances, "community" referred to the supportive housing unit in which the respondents live, or the community of psychiatrically disabled. In other instances, "community" refers to the immediate geographical the area in which they live.) Six reasons (highlighted in Table 2) out of sixteen seem to be related in some way to the stigma of their mental illness. They account for $50 \%$ of all reasons mentioned.

Table 2. Reasons for volunteering

\begin{tabular}{|llll}
\hline Reasons & Frequency & $\begin{array}{l}\text { \% of } \\
\text { responses }\end{array}$ & $\begin{array}{l}\text { \%of } \\
\text { respondents }\end{array}$ \\
\hline Opportunities to meet with people & $\mathbf{8}$ & $\mathbf{1 4 . 5}$ & $\mathbf{2 8 . 6}$ \\
\hline Reason to get out of the house & 7 & $\mathbf{1 2 . 7}$ & $\mathbf{2 5}$ \\
\hline Help others & 7 & 12.7 & 25 \\
\hline Have ideas respected & $\mathbf{5}$ & $\mathbf{9 . 0 9}$ & $\mathbf{1 7 . 9}$ \\
\hline Involvement in/giving back to community & 4 & 7.27 & 14.3 \\
\hline Satisfaction & $\mathbf{4}$ & $\mathbf{7 . 2 7}$ & $\mathbf{1 4 . 3}$ \\
\hline Offers creative expression & $\mathbf{3}$ & $\mathbf{5 . 4 5}$ & $\mathbf{1 0 . 7}$ \\
\hline Honorarium/metro-pass & 3 & 5.45 & 10.7 \\
\hline Enjoy learning & 3 & 5.45 & 10.7 \\
\hline Confidence building & $\mathbf{3}$ & $\mathbf{5 . 4 5}$ & $\mathbf{1 0 . 7}$ \\
\hline
\end{tabular}




\begin{tabular}{|llll}
\hline Help organize & 2 & 3.64 & 7.14 \\
\hline Instead of work & 2 & 3.64 & 7.14 \\
\hline Social action & 1 & 1.82 & 3.57 \\
\hline Only job offered & 1 & 1.82 & 3.57 \\
\hline Can't donate, give time instead & 1 & 1.82 & 3.57 \\
\hline “Economy of the heart is greater than money” & 1 & 1.82 & 3.57 \\
\hline Total & 55 & 100 & 196 \\
\hline
\end{tabular}

\section{Support and training}

Seventy-seven percent of our respondents got support and/or training at their volunteer placements: $40 \%$ had orientation and training, 27\% got general help, $20 \%$ were under regular supervision, and 13\% learned from volunteers. Eighty percent thought the support they received was very helpful; the remainder thought it was somewhat helpful.

\section{Current volunteering experiences}

Just under two-thirds (64\%) of the respondents experienced no difficulties in their placement, however among the remaining third, $40 \%$ had problems adjusting to staff members and $30 \%$ had trouble learning new skills. Table 3 presents the full list of difficulties mentioned.

Table 3. Difficulties experienced in current volunteer placement

\begin{tabular}{|c|c|c|}
\hline & Frequency & $\begin{array}{l}\% \text { of } \\
\text { respondents }\end{array}$ \\
\hline None & 18 & 64 \\
\hline Some & 10 & 36 \\
\hline Areas of difficulty & & $\begin{array}{l}\% \\
\text { respondents } \\
\text { w/difficulty }\end{array}$ \\
\hline Adjusting to staff members & 4 & 40 \\
\hline Learning new skills & 3 & 30 \\
\hline Lack of routine & 2 & 20 \\
\hline Adjusting to schedules/time of meeting & 2 & 20 \\
\hline Physical demands & 2 & 20 \\
\hline Self esteem issues & 1 & 10 \\
\hline Communication issues & 1 & 10 \\
\hline \multirow[t]{3}{*}{ Lack of cohesion } & 1 & 10 \\
\hline & 16 & \\
\hline & & 150 \\
\hline
\end{tabular}

Eighty percent of the respondents claimed they enjoyed volunteering very much, 15\% enjoyed it somewhat and 5\% qualified it by saying that sometimes they enjoyed it but sometimes they did not. Table 4 lists the reasons they gave for their enjoyment. Unlike their motivations for 
volunteering, the predominant reason given for enjoying their volunteer placement was that it provided them with an opportunity to "give

back" to the community and help others (32\%). Interacting with others was mentioned by $21 \%$ of respondents. Almost all of the other reasons, however, related to their own sense of well being.

Table 4. Reasons for enjoying volunteering.

\begin{tabular}{llll}
\hline Reasons & Frequency & $\begin{array}{l}\text { \% of } \\
\text { responses }\end{array}$ & $\begin{array}{l}\text { \% of } \\
\text { respondents }\end{array}$ \\
\hline Give back to community/help others & 9 & 24.3 & 32.1 \\
\hline Interaction with others & 6 & 16.2 & 21.4 \\
\hline Sense of accomplishment & 6 & 16.2 & 21.4 \\
\hline Get out of the house/good use of time & 5 & 13.5 & 17.9 \\
\hline Like the work & 4 & 10.8 & 14.3 \\
\hline Better appreciate self & 3 & 8.11 & 10.7 \\
\hline Keeps mind and body active & 1 & 2.7 & 3.57 \\
\hline Escape stigma of mental illness & 1 & 2.7 & 3.57 \\
\hline Passion for volunteering & 1 & 2.7 & 3.57 \\
\hline Staff & 1 & 2.7 & 3.57 \\
\hline Total & 37 & 100 & 132 \\
\hline
\end{tabular}

The most rewarding aspects of volunteering were also helping people and the community followed by socializing and working with others. However, several respondents mentioned the rewards of learning new things and seeing the impact of their volunteering on others.

Table 5. The most rewarding aspects of volunteering

\begin{tabular}{llll}
\hline Aspects & Frequency & $\begin{array}{l}\text { \% of } \\
\text { responses }\end{array}$ & $\begin{array}{l}\text { \% of } \\
\text { respondents }\end{array}$ \\
\hline Helping people and the community & 9 & 28.1 & 32.1 \\
\hline Socialization/working with others & 7 & 21.9 & 25 \\
\hline Learning new things & 4 & 12.5 & 14.3 \\
\hline Increased self confidence/self-esteem & 4 & 12.5 & 14.3 \\
Every aspect & 4 & 12.5 & 14.3 \\
\hline Seeing results and impact on others & 2 & 6.25 & 7.14 \\
Working with staff & 1 & 3.13 & 3.57 \\
Freedom & 1 & 3.13 & 3.57 \\
\hline Total & 32 & 100 & 114 \\
\hline
\end{tabular}

Not all experiences were rewarding however. The most frequently mentioned irritant related to volunteering was conflict followed by a sense of under-appreciation and a lack of challenge. For a complete list please see Table 6. 
Table 6. Least rewarding aspects of volunteering

\begin{tabular}{llll}
\hline Aspects & Frequency & $\begin{array}{l}\text { \% of } \\
\text { responses }\end{array}$ & $\begin{array}{l}\text { \% of } \\
\text { respondents }\end{array}$ \\
\hline Conflicts & 6 & 33.3 & 21.4 \\
\hline Under Appreciation & 3 & 16.7 & 10.7 \\
\hline Lack of challenge & 2 & 11.1 & 7.14 \\
\hline Doing things no one else will do & 2 & 11.1 & 7.14 \\
\hline Not knowing the full impact of efforts & 1 & 5.56 & 3.57 \\
\hline Wasted time & 1 & 5.56 & 3.57 \\
\hline Location & 1 & 5.56 & 3.57 \\
\hline Paperwork & 1 & 5.56 & 3.57 \\
\hline Insufficient staffing & 1 & 5.56 & 3.57 \\
\hline Total & 18 & 100 & 64.3 \\
\hline
\end{tabular}

When asked about the personal gains they got from volunteering, our respondents focused more on internal gains, related to feelings, rather than to gains related to skills or social networking. The three most frequently mentioned personal gains were: a sense of accomplishment, a good feeling and increased confidence, self-esteem and/or empowerment. These accounted for almost half of all the gains mentioned. Skill acquisition accounted for $17 \%$ and four people claimed that volunteering gave them a reason for living or saved their lives. See Table 7.

Sixty percent of the respondents indicated that they would like to volunteer more, but could not because they had too many other things to do and had no time (50\%), or they were in poor health or could not find placements. One respondent said it was to keep options open for paid work. Of those who had no desire to volunteer more, half found it too stressful, could not handle more or were in poor health and the other half wanted to do other things in life including waiting for paid work.

Close to $70 \%$ of the respondents felt that there were no disadvantages to volunteering. The remainder sited lack of remuneration $(\mathrm{N}=3)$, burnout and lack of challenge $(\mathrm{N}=2)$, too much work, physically demanding and being "taken advantage of" ( $\mathrm{N}=1$ each).

Table 7. Personal gain from volunteering

\begin{tabular}{llll}
\hline Personal gain & Frequency & $\begin{array}{l}\text { \% of } \\
\text { responses }\end{array}$ & $\begin{array}{l}\text { \% of } \\
\text { respondents }\end{array}$ \\
\hline Sense of accomplishment & 7 & 17.9 & 25 \\
\hline A good feeling & 6 & 15.4 & 21.4 \\
\hline Increased confidence/self-esteem/empowerment & 6 & 15.4 & 21.4 \\
\hline Keeping busy & 4 & 10.3 & 14.3 \\
\hline Reason for living/saved life & 4 & 10.3 & 14.3 \\
\hline Met new people & 4 & 10.3 & 14.3 \\
\hline Gained skills, helped get paid position & 3 & 7.69 & 10.7 \\
\hline Learned new things & 2 & 5.13 & 7.14 \\
\hline Learned patience & 1 & 2.56 & 3.57 \\
\hline
\end{tabular}




\begin{tabular}{llll}
\hline Leadership skills & 1 & 2.56 & 3.57 \\
Kept abreast of community affairs & 1 & 2.56 & 3.57 \\
& 39 & 100 & 139 \\
\hline
\end{tabular}

\section{Impact of volunteering}

Since there are consumer survivors and professional workers who are against clientvolunteering, claiming that the work done through volunteering should be paid, we asked our respondents whether volunteering has affected their prospects for getting paid work. Fifty-seven percent did not think so. The remaining respondents who did say that volunteering had an impact, pointed to positive reasons. They felt the skills they acquired while volunteering would give them better job prospects. One person said that he found a paid job through volunteering. When asked whether volunteering had an impact on their community connectedness, 85\% of respondents said yes because working with, being with and helping others gave them a sense of connectedness.

We also asked whether volunteering had any impact on their mental and physical wellbeing. Almost half of the respondents said they felt better about themselves, had more pride and self-esteem. Another third talked about peace of mind and acceptance of their illness. Twentynine percent claimed an improvement in the quality of their lives. Table 8 lists all the ways in which volunteering affected their well-being.

Table 8. Effect of volunteering on well-being

\begin{tabular}{llll}
\hline Effect & Frequency & $\begin{array}{l}\text { \% of } \\
\text { responses }\end{array}$ & $\begin{array}{l}\text { \% of } \\
\text { respondents }\end{array}$ \\
\hline Feel better about self/pride/self-esteem & 13 & 29.5 & 46.4 \\
\hline $\begin{array}{l}\text { Peace of mind/better spirit/more accepting of mental } \\
\text { illness }\end{array}$ & 9 & 20.5 & 32.1 \\
\hline Improved quality of life & & & \\
\hline Personal support/satisfaction & 8 & 18.2 & 28.6 \\
\hline Working with others & 5 & 11.4 & 17.9 \\
\hline More interested in work/things & 4 & 9.09 & 14.3 \\
\hline Better grades & 2 & 4.55 & 7.14 \\
\hline No effect & 1 & 2.27 & 3.57 \\
& 2 & 4.55 & 7.14 \\
\hline
\end{tabular}

Our final question asked the respondents: "If someone wanted to set up a volunteer program for people with psychiatric disabilities, what would you suggest is necessary to create a successful volunteer program?” Table 9 lists their suggestions. By far the most important feature for a successful program was related to support and supervision, followed by a variety of interesting activities. 
Table 9. Suggested features for a good volunteer program.

\begin{tabular}{llll}
\hline Suggestions & Frequency & $\begin{array}{l}\text { \% of } \\
\text { responses }\end{array}$ & $\begin{array}{l}\text { \% or } \\
\text { respondents }\end{array}$ \\
\hline $\begin{array}{l}\text { Support/supervision/training/feedback/appreciation } \\
\begin{array}{l}\text { Variety and interesting activities to match skills and } \\
\text { talent }\end{array}\end{array}$ & 7 & 30.4 & 25 \\
\hline $\begin{array}{l}\text { Flexibility } \\
\text { Clearly defined rules and expectations }\end{array}$ & 2 & 17.4 & 14.3 \\
\hline $\begin{array}{l}\text { Financial appreciation/honorarium/transit costs } \\
\text { Treat as equals, not as mentally ill }\end{array}$ & 2 & 8.7 & 7.14 \\
\hline $\begin{array}{l}\text { Provide opportunities for group activities to meet } \\
\text { friends }\end{array}$ & 2 & 8.7 & 7.14 \\
\hline $\begin{array}{l}\text { Start locally } \\
\text { Educate people about mental illness }\end{array}$ & 2 & 8.7 & 7.14 \\
\hline Total & 1 & 8.7 & 7.14 \\
\hline
\end{tabular}

\section{Discussion and conclusions}

Although volunteering is generally viewed in a positive manner, this is not always true for people with disabilities. In fact, for some people there is a stigma associated with volunteering. People with disabilities typically experience significant barriers to obtaining paid employment. This persists, even though in recent years a number of training and employment initiatives have been instituted to support people with disabilities in obtaining and keeping paid jobs. According to the Canadian Council on Social Development, in the year 2000, 46.7\% of women and $36.5 \%$ of men with disabilities were not gainfully employed. This stands in stark contrast to the general, non-disabled population, where only $22.5 \%$ of non-disabled women and $12.8 \%$ of non-disabled men were unemployed. Thus, three times as many disabled men and twice as many disabled women were out of work than their non-disabled peers. For disabled people who want to work, having to resort to volunteering can indeed be perceived as a stigma.

This was not evident, however, in our sample of respondents, where only one person felt being taken advantage of. .Nevertheless, it is important to note a limitation of this study. Our sample is a purposive one where volunteers volunteered to talk to us about their experiences. They either lived in supportive housing that offered volunteer opportunities, or were affiliated with an agency, or day club or drop in centre serving people with psychiatric disabilities. We were unable to reach people who were volunteering outside these settings. Nor were we able to reach consumer survivors who were not volunteering for whatever reasons.

The data from our limited sample clearly indicate that among our respondents volunteering is a positive experience, providing them with opportunities to get out of the house, socialize, learn new things, and while doing all this, also help others and give something back to the community. Our respondents also reported that volunteering had positive benefits on their mental health. In fact, the benefits of volunteering are expressed in answers to several of our questions. It is important to note that the findings reported in this paper are based on open-ended answers to questions about volunteering. The answers therefore, reflect the immediate and 
unprompted feelings of the respondents. The consistency of the answers to questions probing different aspects of the volunteering experience serves to reinforce the strength of these feelings and opinions.

Our respondents reported very few disadvantages to volunteering or difficulties in their placements. The difficulties they reported were related to adjustment problems and to learning new skills. Both the benefits and the difficulties they reported closely parallel the benefits and personal barriers reported by our expert key informants in the first phase of this study, reported at last year's Arnova conference.

In conclusion, despite some concerns that volunteering may be an unfair replacement to for paid work, our sample of respondents felt that volunteering was beneficial to them in many ways. This reflected the opinions of the expert key informants interviewed in Phase 1 of this study.

\section{References}

Besio, S. \& Mahler, J. (1993). Benefits and challenges of using consumer staff in supported housing services. Hospital and Community Psychiatry 44(1), 490-491.

Chipperfield, S., \& Aubrey, T. (1990). The supportive housing program in Winnipeg. Psychosocial Rehabilitation Journal, 13(4), 91-95.

Cook, J. \& Pickett, S. (1994). Recent trends in vocational rehabilitation for people with psychiatric disability. American Rehabilitation 20(4), 2-12.

CPA. (1999). Canadian Psychiatric Association Press Release. (September 15, 1999). www.cpa-acp.org/PR_Sep15_99

Crawford, C. (2004). Improving the odds: Employment, disability and public programs in Canada. Toronto, ON: Roeher Institute.

CVBOC. (1988). Volunteering: A pathway to integration. Ottawa: The Central Volunteer Bureau of Ottawa-Carleton.

Firth, M. \& Kerfoot, M. (1997). Voices in partnership: involving users and carers in commissioning and delivering mental health services. NHS Health Advisory Service thematic review. London: Stationery Office.

Erickson, B.H. (1979). Some problems of inference from chain data. Sociological Methodology 10, 276-302

Goering, P. (2004). Making a difference: Ontario's Community Mental Health Evaluation Initiative. Government of Ontario: Community Mental Health Evaluation Initiative. www.ontario.cmha.ca/Making_a_Difference.pdf

Goodman, L.A. (1961). Snowball sampling. Annals of Mathematical Statistics 32, 148-170

Graff, L. (1998). Literature review: Supported volunteering. Kitchener: Opportunities for All. 
Graff, L. (1992). Special needs volunteering: A directory of programs in Canada. Etobicoke: Volunteer Ontario, The Centre for Volunteerism.

Health Canada. (2001). A report on mental illness in Canada. www.hc-sc.gc.ca/

Itzhaky, H., \& Schwartz, C. (1998). Empowering the disabled: A multidimensional approach. International Journal of Rehabilitation Research, 21(3), 301-310.

Knowles, C. (2000). Bedlam on the streets. London; New York: Routledge.

Lautenschlager, J. (1992). Bridges to the future: Supported programs for volunteers with special needs. Ottawa: Canadian Heritage.

Lurie, S. (2004). Comparative mental health policy: Are there lessons to be learned? Paper presented at ICONS: The International Conference on Schizophrenia, Chennai, India. www.toronto.cmha.ca/comparative mental health policy.pdf

Macias, C., Kinney, R., \& Rodican, C. (1995). Transitional employment: An evaluative description of fountain house practice. Journal of Vocational Rehabilitation, 5, 151-157.

MacKinnon, J. (1991). Volunteer access: A manual for special needs volunteering. Victoria, BC: Victoria Volunteer Bureau.

Mowbray, C., Moxley, D. et al. (1996). Consumers as community support providers: Issues created by role innovation. Community Mental Health Journal 32(1), 47-67.

Nelson, G., Lord, J., \& Ochocka, J. (2001). Shifting the paradigm in community mental health: Towards empowerment and community. Canada: University of Toronto Press.

Nelson, G., Ochocka, J., Janzen, R., \& Trainor, J. (2006). A longitudinal study of mental health Consumer/Survivor initiatives: Part 2-A quantitative study of impacts of participation on new members. Journal of Community Psychology, 34(3), 261-272.

ODHC. (2003). From practice to policy: Report of the health human resources capacity and utilization project. Toronto: Ontario District Health Councils and the Ministry of Health and Long-Term

Care. www.dhcarchives.com/ODHC_HHR Final Report.pdf

Ontario Ministry of Health. (1988). Building community support for people: A plan for mental health in Ontario. Toronto, ON: The Provincial Community Health Committee (Robert Graham, chairman).

Ontario Ministry of Health. (1993). Putting people first: the reform of mental health services in Ontario. Toronto, ON: Ontario Ministry of Health. 
Pyle, R. (1997). Pathways: A guide to involving persons with disabilities in volunteer programs. Calgary, AB: Volunteer Calgary.

Roeher Institute. (1990). Deinstitutionalization in Canada: An annotated bibliography. Downsview, ON: Roeher Institute.

Roeher Institute. (1999). Towards inclusion: National evaluation of deinstitutionalization initiatives. Toronto: Roeher Institute.

Schmidl, B. (2005). Simple solutions: a manual - how NGOs can eliminate barriers to volunteering by people with disabilities. Toronto: Imagine Canada.

Sealy, P., \& Whitehead, P. (2004). Forty years of de-institutionalization of psychiatric services in Canada: An empirical assessment. Canadian Journal of Psychiatry, 49(4), 249-257.

Shimrat, I. (1997). Call Me Crazy: Stories from the Mad Movement. British Columbia: Press Gang Publishers.

Simmons, H. (1990). Unbalanced: Mental health policy in Ontario 1930-1989. Canada: Wall \& Thompson.

Statistics Canada. (2002). A profile of disability in Canada, 2001. Ottawa: Statistics Canada.

Stroman, D. (2003). The disability rights movement: From deinstitutionalization to selfdetermination. Lanham, MD: University Press of America.

VDS. (2005). Volunteering \& disability: Experiences and perceptions of volunteering from disabled people and organizations. Stirling: Volunteer Development Scotland.

Volunteer Canada. (2001). Volunteer connections: Creating an accessible and inclusive environment. www.volunteer.ca/AccessEnglish.pdf

Weaver, J. (1993). An untapped resource: Working with volunteers who are mentally ill. Walla Walla, WA: MacDuff Bunt Associates. 